\title{
AN ENERGY AUDIT OF AN INDUSTRY: A CASE STUDY
}

\author{
DIGVIJAY B. KANASE \& VISHAL B. PATIL
}

Annasaheb Dange College of Engineering \& Technology, Ashta, Maharashtra, India

India is a developing country and electrical energy consumption byindustries is about $60 \%$ of the total energy consumption. The industrial development in the country is progressing at a fast pace due to the increase in the number of industries, the gap between demand and supply of electricity is also increasing day by day. To minimize this gap the best solution is to conductan energy audit of all industries on regular bases. The energy audit will determine energy wastage and losses, and provide techniques and ways to minimize the losses. The energy consumption techniques suggested by the energy audit will not only minimize the losses but also reduce monthly electricity bill. This paper suggests ways and means to conduct an energy audit in an industry
\end{abstract}

KEYWORDS: Energy Audit, Energy Consumption, Energy Conservation, Power Factor Surcharge, Payback Period, Energy Audit Phase \& Energy Conservation Opportunities (ECOs)

Received: Dec 12, 2018; Accepted: Jan 02, 2019; Published: Jan 29, 2019; Paper Id: IJEEERJUN20193

\section{INTRODUCTION ENERGY}

Audit is defined as the verification, monitoring and analysis of energy use, including submission of technical report containing all the recommendations for improving energy efficiency with cost analysis and an action plan to reduce consumption [1]. In general energy audit is the translation of conservation ideas into realities by lending technically feasible solutions with economics and other organizational considerations within a specified time frame [2]. The energy audit was conducted at Laxmi sales and services, 1325/ 43, ShivajiUdayamnagar, Kolhapur- 416008, Maharashtra, India. The energy audit was conducted within a period of one week. The above industry does the repair and maintenance of pumps, motors, etc. of their own production and also sales the motors and pumps, essential for agriculture and domestic purpose. This industry has a sanctioned load at $440 \mathrm{~V}$, is $6 \mathrm{~kW}$ and it comprises of different sections like service department, spare department, office and printing home. It has many types of equipment and heavy machinery like grinder, drill machine, lathe machine, press machine, submersible pump, welding sets.

\section{MAIN OBJECTIVES}

The proposed work will cover following sections.

\subsection{Audit Phase- I (Pre-Audit Phase)}

During pre-audit phase the following observations/inspection were completed within two days as per the schedule given in Table 1. 
Table 1: Schedule of Energy Audit Phase -I

\begin{tabular}{|c|l|c|}
\hline S. No. & \multicolumn{1}{|c|}{$\begin{array}{c}\text { Observations/ } \\
\text { Inspection }\end{array}$} & Result \\
\hline 1 & $\begin{array}{l}\text { A complete walk } \\
\text { through in the industry }\end{array}$ & Done \\
\hline 2 & $\begin{array}{l}\text { Discuss advantages of } \\
\text { energy audit }\end{array}$ & Done \\
\hline 3 & $\begin{array}{l}\text { Inspect various sections } \\
\text { for any energy wastage }\end{array}$ & See Table-2 \\
\hline 4 & $\begin{array}{l}\text { Prepare a list of major } \\
\text { energy consuming } \\
\text { machinery with their } \\
\text { ratings }\end{array}$ & $\begin{array}{l}\text { See Table-3 } \\
\text { required for audit }\end{array}$ \\
\hline 5 & $\begin{array}{l}\text { Calculate lighting and } \\
\text { machine load }\end{array}$ & See Table-4 \\
\hline 7 & $\begin{array}{l}\text { Check any loose } \\
\text { connection and leakage }\end{array}$ & $\begin{array}{c}\text { No any loose } \\
\text { connection and leakage }\end{array}$ \\
\hline 8 & $\begin{array}{l}\text { Prepare a visual } \\
\text { inspection report }\end{array}$ & See Table-5 \\
\hline 9 & $\begin{array}{l}\text { Suggestion and ECOs } \\
\text { for Pre-audit Phase-I }\end{array}$ & See Table-6 \\
\hline
\end{tabular}

Table 2: Machines and Equipment in Industry

\begin{tabular}{|l|l|c|c|}
\hline S. no & Name of Machine/ Equipment & Quantity & Capacity \\
\hline 1 & Grinder & 1 & $750 \mathrm{~W}$ \\
\hline 2 & Lathe machine & 1 & $750 \mathrm{~W}$ \\
\hline 3 & Drill machine & 1 & $1075 \mathrm{~W}$ \\
\hline 4 & Press machine & 1 & $1075 \mathrm{~W}$ \\
\hline 5 & Submersible pump & 1 & $1500 \mathrm{~W}$ \\
\hline 6 & welding sets & 5 & $8 \mathrm{~kW}$ each \\
\hline
\end{tabular}

Table 3: Instruments Required for Energy Audit

\begin{tabular}{|c|l|}
\hline Sr No & Name of Instruments \\
\hline 1 & Digital Multimeter \\
\hline 2 & Digital Techometer \\
\hline 3 & Clip on meter \\
\hline 4 & Lux meter \\
\hline 5 & Power factor meter \\
\hline
\end{tabular}

Table 4: Lighting Load Calculation of Laxmi Sales and Services

\begin{tabular}{|c|l|c|c|c|c|c|c|}
\hline $\begin{array}{c}\text { S. } \\
\text { No }\end{array}$ & \multicolumn{1}{|c|}{ Type of Load } & Office & $\begin{array}{c}\text { Service } \\
\text { Department }\end{array}$ & $\begin{array}{c}\text { Spare } \\
\text { Department }\end{array}$ & $\begin{array}{c}\text { Printing } \\
\text { Home }\end{array}$ & Cabin & $\begin{array}{c}\text { Open } \\
\text { Space }\end{array}$ \\
\hline 1 & CFL (40W) & 15 & 10 & 14 & 3 & 44 & 3 \\
\hline 2 & Fan(1 00W) & 11 & 6 & 2 & 4 & 11 & - \\
\hline 3 & Printer (800 W) & 6 & 1 & 1 & - & - & - \\
\hline 4 & Xerox machine(10 00W) & 1 & - & - & - & - & - \\
\hline 5 & Computers (25W) & 15 & 3 & 2 & - & 11 & - \\
\hline 6 & AC (1000 W) & - & - & - & - & 11 & - \\
\hline 7 & Projector(1 500W) & - & - & - & 1 & - & - \\
\hline 8 & Total load in watts & $7875 \mathrm{~W}$ & $1875 \mathrm{~W}$ & $1610 \mathrm{~W}$ & $2020 \mathrm{~W}$ & $14135 \mathrm{~W}$ & $120 \mathrm{~W}$ \\
\hline
\end{tabular}

Total lighting load $=7875+1875+1910+2020+14135+120=27935 \mathrm{~W}$ 
Table 5: Machine Load (Connected) Calculation of Laxmi Sales and Services

\begin{tabular}{|c|l|c|}
\hline S No. & \multicolumn{1}{|c|}{ Machine } & Load in Watts \\
\hline 1 & Grinder & $750 \mathrm{~W}$ \\
\hline 2 & Lathe machine & $750 \mathrm{~W}$ \\
\hline 3 & Drill machine & $1075 \mathrm{~W}$ \\
\hline 4 & Press machine & $1075 \mathrm{~W}$ \\
\hline 5 & Submersible pump & $1500 \mathrm{~W}$ \\
\hline 6 & Welding sets & $40000 \mathrm{~W}$ \\
\hline & Total Machine Load & $45150 \mathrm{~W}$ \\
\hline
\end{tabular}

Table 6: Visual Inspection Report of Pre-audit Phase-I

\begin{tabular}{|c|l|}
\hline S No. & \multicolumn{1}{c|}{ Deficiency found in the Industry } \\
\hline 1 & 30 tubes connected with traditional chokes. \\
\hline 2 & Tubes in the cabin were ON even inthe day. \\
\hline 3 & Deficiency of proper ventilation in the service department \\
\hline
\end{tabular}

Table 7: Suggestion and ECOs for Pre-audit Phase-I

\begin{tabular}{|c|l|}
\hline S No. & \multicolumn{1}{|c|}{ Suggestion for Pre-Audit Phase 1 } \\
\hline 1 & Replacing with ballast choke \\
\hline 2 & Switching off the tubes when not required \\
\hline 3 & Adding number of tubes in service department \\
\hline
\end{tabular}

Table 8

\begin{tabular}{|c|c|c|c|c|}
\hline S No. & Month & Power Factor & $\begin{array}{c}\text { Energy } \\
\text { Consumption } \\
\text { in kWh }\end{array}$ & Electricity Bill \\
\hline 1 & October 2017 & 0.87 & $4589 \mathrm{kWh}$ & $22947.75 \mathrm{rs}$ \\
\hline 2 & November 2017 & 0.86 & $5000 \mathrm{kWh}$ & $25000 \mathrm{rs}$ \\
\hline 3 & December 2017 & 0.87 & 4986 & $24930 \mathrm{rs}$ \\
\hline 4 & January 2018 & 0.895 & 3600 & $18000 \mathrm{rs}$ \\
\hline 5 & February 2018 & 0.880 & 3719 & $18595 \mathrm{rs}$ \\
\hline 6 & March 2018 & 0.86 & 4000 & $20000 \mathrm{rs}$ \\
\hline 7 & April 2018 & 0.854 & 5960 & $29800 \mathrm{rs}$ \\
\hline 8 & May 2018 & 0.844 & 3012 & $15060 \mathrm{rs}$ \\
\hline 9 & June 2018 & 0.87 & 4033 & $20165 \mathrm{rs}$ \\
\hline 10 & July2018 & 0.89 & 4123 & $20615 \mathrm{rs}$ \\
\hline 11 & August 2018 & 0.81 & 3258 & $16290 \mathrm{rs}$ \\
\hline 12 & September 2018 & 0.88 & 3698 & $18490 \mathrm{rs}$ \\
\hline
\end{tabular}

\subsection{Audit Phase-II}

During audit phase II the following observationswerecompletedwithin2days. The summary of electricity bills of 12 months since October 2017 to October 2018. 


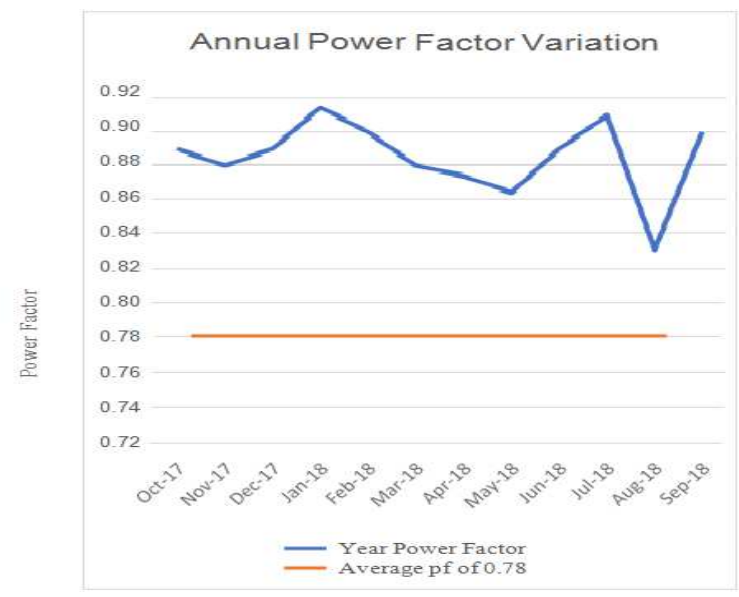

Figure 1: Power Factor v/s Months

Figure 1 shows the monthly power factor variation in a year.

\section{3 kVAr Calculation for Industry}

According to the electrical data given below the required $\mathrm{kVAr}$ or capacitor bank can be calculated to maintainthepower factor of 0.95 to reduce the powerfactor surchargebecausetheelectricalutilityshall be apply a power factor clause for those consumers who have not maintain the average power factor of 0.90. In case the average power factor falls below 0.9(90\%), a surcharge @1\% of energy charges for every $0.01(1 \%)$ fall in average power factor below $0.90(90 \%)$, shall be charged. Also, an incentive of $1 \%$ of energy charges shall be provided if power factor is above 0.95(95\%)foreach0.01(1\%)improvementabove 0.95(95\%) [5].

Average power factor (during the year October 2017 to September 2018) $=0.78$ (Referring Figure 1)

Required power factor $=0.95$. The power factor is defined as the ratio of true or real power in $\mathrm{kW}$ to apparent power in $\mathrm{kVA}$.

Therefore, Power factor $(\cos \Phi)=\mathrm{kW} / \mathrm{kVA}$

$$
(\mathrm{KVA})^{2}=(\mathrm{KW})^{2}+(\mathrm{KVAR})^{2}
$$

$$
\operatorname{KVAR}=\sqrt{ }(\mathrm{KVA})^{2}-(\mathrm{KW})^{2}
$$

The required $\mathrm{kVAr}$ can be calculated from the above equation 2. If the power factor is improvedfrom0.78to0.95thiswillreduce the power factor surcharge. The required kVAr or capacitor bank can be calculated from the Figure2 givenbelow. 


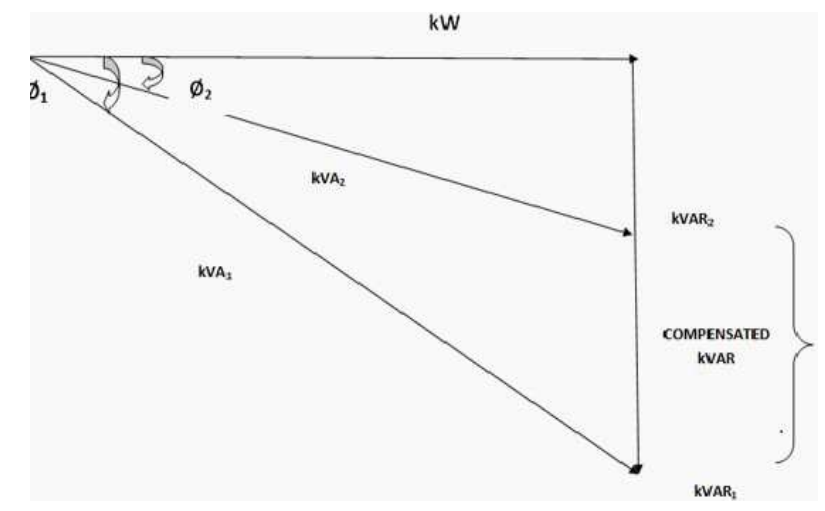

Figure 2: Power Factor Correction

The required $\mathrm{kVAr}$ will be calculated as under $\tan { }^{\imath} 1=\mathrm{AC} / \mathrm{OA}, \mathrm{OA}=\mathrm{P}(\mathrm{kW})$.

Therefore, $\mathrm{AC}=\mathrm{Ptan} 1 \mathrm{And} \mathrm{AB}=\mathrm{Ptan} 2 \mathrm{BC}=\mathrm{AC}-\mathrm{AB}$, put the values weget

$\mathrm{BC}=\mathrm{P} \tan 1-\mathrm{P} \tan 2$ and $\mathrm{BC}=\mathrm{Q}(\mathrm{kVAr})$

$\mathrm{Q}(\mathrm{kVAr})=\mathrm{P}\left(\tan ^{0} 1-\tan ^{2} 2\right)$

Put the values of $\mathrm{P}=96.98$

$\begin{aligned} \mathrm{Q}(\mathrm{kVAr}) & =96.98[\tan (38.73)-\tan (18.194)] \mathrm{Q}(\mathrm{kVAr}) \\ & =46.044, \text { say47kVAr }\end{aligned}$

(approximately)

\subsection{Calculation of Payback Period for Implementation of ECOs}

- Annual energy savings (due to replacement of ballast)

$=[30($ T.L $) \times 40(\mathrm{~W}) \times 12(\mathrm{hr}) \times 365(\mathrm{~d}) \times 7.5$

(Rs/kWh)] / 1000

$=39420 \mathrm{Rs}$

where,

T.L = tube lights

$\mathrm{W}=$ wattage of each traditional chokes $\mathrm{hr}=$ no. of hours in a day

$\mathrm{d}=$ total no. of days in a year $\mathrm{Rs} / \mathrm{Kwh}=$ rate of each unit

- Income from selling of old traditional chokes

$=30 \mathrm{x} @ \operatorname{Rs} 50=\mathrm{Rs} 1500$

TotalInvestmentwillbe $=$ TotalInvestment on Hardware - Income from Selling Old Chokes $=39420-1500$

Total Investment=37920rs Net Savings will be=39240rs 
We know that Payback period in year willbe given as $=\frac{\text { Total Annual Investment }}{\text { Net Annual Savings }}=\frac{37920}{39240}$

Total Payback period $=0.966$ years Payback period in months $=0.966 \times 12=11.59=12$

\section{CONCLUSIONS}

- The payback period of the energy audit programmed for Laxmi sales and services industrywillbe12 months; implementation of ECOs is being carried out and will be completed by late year 2019 .

- It is believed that energy audit is one of the most comprehensive methods in achieving energy savings in industry thus reducing excessive energy consumption if all private sector participates in the implementation of the energy audit programs in their industry so that, wasteful consumption of energy will beminimized.

- The replacement of traditional welding sets with IGBT welding sets is not beneficial to the factory, no doubt they operate at good p.f and small initial current but their cost and the maintenance cost is also very high that increases in thepayback period.

- The implementation of energy saving measures suggested in this paper is solely dependent upon the decision of the management of the factory. Several ECOs that are cost effective are not often implementedduetolackofinternalfunding such as installation of IGBT weldingsets.

\section{ACKNOWLEDGMENTS}

I would like to express gratitude to Laxmi sales and services for providing this opportunity in conducting the audit.

\section{REFERENCES}

1. Mehulkumar J Panchal,VedVyas Dwivedi and RajendraAparnathi- TheCase study of Energy Conservation and Audit in Industry Sector International Journal of Engineering and Computer Science, Vol.3, Issue, pp 5298- 5303,April,2014.

2. UmeshRathore, A Referencebook - EnergyManagementpublishedby S.K.Katariaand Sons.

3. PutriZalilaYaacob and Abdullah AsuhainiMohd.ZinElectical, Energy management in Small and Medium Size Industries\| Proceedings of Conference on Computer, Communication, Control and Power Engineering, Vol.5, Bgijng, China, pp 379382, October, 1993.

4. Jokthan, G. E. (2013). Effect of Different Energy Sources on Intake and Weight Gain of White Fulani Cattle. International Journal of Research in Applied, Natural and Social Sciences, 1(5), 1-8.

5. Jaipur Discom,Tariff for supply of Electricity2012,designed and produced by Jaipur VidyutVitranNigamLimited.

6. http://www.havells.com

7. S.L Uppal, A Referencebook - Electrical wiring and estimating costing by Khanna publishers, Delhi-6.

8. Bai, B. J., \& KUMAR, C. R. (2014). Dynamic Model and Control of DFIG Wind Energy Systems Based on Power Transfer Matrix using SVPWM. International Journal of Electrical and Electronics Engineering (IJEEE), 3(1), 27-36.

9. CheeKhiang Pang, Cao Vinh Le, Oon Peen Gan, Xiang Min Chee, Dan Hong Zhang,MingLuo, HianLeng Chan, and Frank L. Lewis.-Intelligent Energy Audit and Machine Management for Energy-Efficient Manufacturing\| Proceeding of International Conference on Cybernetics and Intelligent Systems (CIS), Qingdao, pp 142-147, September,2011 